\title{
THEMATIC SCIENTIFIC INTERPRETATION OF THE QUR'AN IN INDONESIA
}

\author{
M. Anwar Syarifuddin \\ Syarif Hidayatullah State Islamic University (UIN) Jakarta \\ anwar.syarifuddin@uinjkt.ac.id \\ Jauhar Azizy \\ Syarif Hidayatullah State Islamic University (UIN) Jakarta \\ jauhar.azizy@uinjkt.ac.id
}

\begin{abstract}
This piece observes the new genre of Qur'an interpretation in modern Indonesia. The research is conducted by way of classifying a related typology for works on the thematic scientific interpretation of the Qur'an published in the period from the 1970s to 2015. Referring to the theory of structural exegesis underlining the significant impact of interpreters' cultural and educational background to the choice of their exegetical styles, it can be discerned that scientific expertise leads to the scientists' high interest to write thematic scientific understanding on the cosmic verses of the Qur'an. Such interest is also evoked by excessive scientific findings that correspond to the Quranic statements. This article concludes that at least there are three categories of thematic scientific interpretations of the Qur'an in Indonesia, namely: (1) works presenting general themes of scientific understanding, (2) works presenting thematic discussions on specific scientific perspectives, and (3) works seeking scientific understanding of the Qur'an as an evidence of its scientific miracles.
\end{abstract}

Keywords: the Qur'an commentary, thematic method of interpretation, the scientific pattern of interpretation, Indonesia.

\section{Introductory Notes on Thematic Interpretation to the Qur'an}

The thematic scientific interpretation of the Qur'an can be categorized as a new genre in writing Qur'an commentaries. Theoretically, the labeling of "thematic scientific works" refers to the varieties of methods and patterns of the Qur'an interpretation from the perspective of 'Abd al-Hayy al-Farmawī (1977). He was commonly referred as of the founders of a thematic method of Qur'an interpretation. However, as there is no rigid procedure of thematic interpretation, one does not necessarily follow al-Farmawi as a suitable formula requires certain modification.

Al-Farmawi classified the Qur'an interpretation into four methods (manhaj):

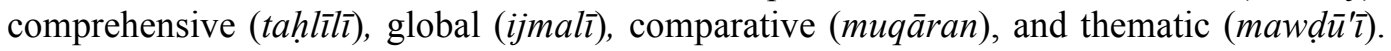
However, he made detailed exploration on varieties of patterns only on the comprehensive method of interpretation. He classified the comprehensive into 7 patterns of interpretations: traditional (ma'th $\bar{u} r)$, rational ( $\left.r a^{\prime} y i\right)$, mystical (sūfi), legal (fiqh), philosophical (falsafì), scientific ('ilmī), and socio-literary pattern (adab ijtimā' $\bar{\imath}$ ). It is highly appropriated to add the patterns to all method of interpretation considering that the recent development of Tafsir literature in Indonesia provides numerous works with so many new styles of interpretation. By the extension, we will have the following chart: 


\section{CLASSIFICATION OF METHODS AND PATTERN OF QUR'AN INTERPRETATION}
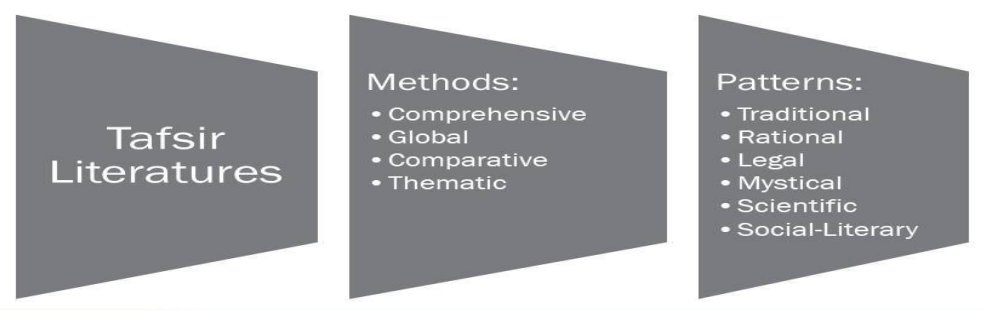

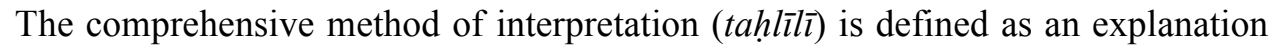
of the verses of the Qur'an by exposing all aspects associated with it. An interpreter gives his explanation of the Qur'an according to the arranged order of the muṣhaf from the beginning to the end, verses after verses in sequence, explaining the meaning of each sentence one after another, and then expressing the message for the whole verse. In addition, the interpreters could also make reviews considering the correlated previous or the next verses (munāsabah), explaining the nucleus binding the desired meaning, connecting the intended purpose, as well as selecting the favorable arguments. They also provide socio-historical contexts of the revelation (asbāb al-nuzūl) and accounts of traditions given by the Prophet, his Companions and their followers, including explanations of lingual problems related to the text.

The global method of interpretation (ijmalī) is meant to be a succinct and global way of explanation given by an exegete of the Qur'an comprising grammatical status $\left(i^{\prime} r \bar{a} b\right)$ or the equivalent (murādif) of the words and phrases within the Quranic verses. Examples of works applying the global method of interpretation are Tafsir Jalälyn by Jalāl al-Dīn al-Maḥallī and Jalāl al-Dīn al-Suyūțī, and al-Tafsìr al-Qur'ān al-Karīm by Muhammad Farīd Wajdī.

The comparative method of interpretation (muqārin) is intended to be a sort of exegetical method by which the exegete performs his interpretation by presenting a number of perspectives from other interpreters. It could also mean that the compiler will also present a number of Qur'an verses, then he displays views of various scholars on those verses. The basic analytical tool employed in this method is the comparative analysis, in which an opinion will be weighed against the others in every theme offered by the verses. Sometimes, the comparative method is also intended as a form of interpretation of the Qur'an in a broader sense, where the exegete compares the Quranic texts with certain verses mentioned in other parts of the Qur'an concerning a subject matter, or it could also be a comparison between the text of the Qur'an and the text of the Hadith whose outward meaning contradicts the Quranic verses (Al-Farmawī 1977: 45-46).

The thematic interpretation $\left(\operatorname{maw} d \bar{u}^{\prime} \hat{\imath}\right)$ method is a method presenting a discussion on compiled verses of the Qur'an on the basis of certain unifying themes, then being sorted in accordance to the chronic of their descent ( $a l$-tartīb al-nuzul $\vec{\imath}$ ) along with backgrounds of the socio-historical context which causes the descent of the verses, explaining their interconnectedness one with the others, any legal rulings (istinba $\bar{t}$ ) can be taken from the verse, and many other explanatory elements. Theoretical studies, as well as practical examples of thematic methods of interpretation, can be seen in al-Farmawī's al-Bidāyah fì

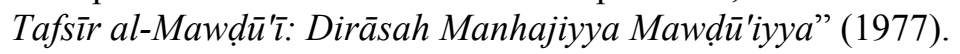

\section{Discourses on Scientific Interpretation (al-Tafsīr al-'Ilmì)}

The reason for the emergence of the scientific pattern of interpretation is that the Qur'an essentially calls for scientific appeal. The call is based on the freedom of reason 
from any doubts and prejudices and even the Qur'an invites a man to contemplate the cosmic phenomenon. Many verses of the Qur'an are closed by laudable phrases such as inna fi dhālika la'āyāt liqawm yatafakkarūn (Really, in that there are signs for those who think), wamā yatadhakkar illā ulu al-albāb "(And no one can take a lesson except those with common sense), la'allakum ta'qilün (for you to understand), or with other phrase "for the thinking people", la'allahum yatafakkarün (so they think).

The above commendable phrases at the end of the verses evoke observers and scientists to explore cosmic verses. They believe that those admirable phrases are directed toward themselves in order to uncover the mystery of divine knowledge through the scientific tools and expertise pertaining to these cosmic verses. They interpret or to some extent derive a scientific understanding of the cosmic verses according to the linguistic rules and usages, their scientific expertise, and then to conclude on the basis of their empirical analysis as well.

Some examples of Qur'an commentaries that belong to the scientific pattern of interpretation are Tafsìr al-Kabīr by Fakhr al-Dīn al-Rāzī and Tafsīr al-Jawāhir by Tanțawī Jauharī. Some scholars also include multi-disciplinary treatises like Ihyā 'Ulūm al-Dīn and Jawāhir al-Qur'ān by Abū Hāmid al-Ghazālī, as well as the compendium of Quranic sciences al-Itqān fì 'Ulūm al-Qur'ān by Jalāl al-Dīn al-Suyūṭ̂̄ among works reflecting the scientific interpretation of the Qur'an (Al-Farmawi 1977: 136).

In his research, Muhammad Ḥussein al-Dhahabī (1995) conveyed a quite similar opinion with al-Farmawī. Both Egyptian Qur'anic scholars did not restrict the application of the classification of both thematic method and scientific pattern of interpretation only for the formal commentary on the full 30 sections (juz') of the Qur'an, because the similarly thematic method and scientific pattern of understanding can also be applied for an interpretive treatise comprising the interpretation of only a chapter (süra) of the Qur'ān. Thus, thematic method and scientific pattern of Qur'anic interpretation can be applied to any kinds of works that might be more accurately referred as treatises or compendiums that specify themselves for particular disciplines employing the cosmic verses (al-Dhahabī, 1995).

\section{The Development of Thematic Scientific Interpretation in Indonesia}

This piece is a continuation of the efforts previously conducted by Howard M. Federspiel (1996), Izza Rohman (2002), and also Islah Gusmian (2003). Looking to what had been done by the previous researchers, we find that Federspiel classified the development of tafsir literature in Indonesia into three generations: (1) from the beginning of the $20^{\text {th }}$ century to the 1960 s being identified as separate translation efforts; (2) attempts to improve the Indonesian translation of the Qur'an to be more integrated in the late 1960s; and (3) from the 1970s the development of the third generation has given the rise of some exhaustive interpretations. In modern Indonesia, the scientific pattern of Qur'anic interpretation emerged as a positive response of the Indonesian exegetes to the contemporaneous development of science and technology. Besides, thematic scientific interpretation of Qur'an has also resulted from the need for major efforts of the writing Qur'anic interpretation in the Indonesian language.

Accordingly, since the 1970s there have been abundant scientific and technological findings, especially by the Western scholars, who passed their information through various communications media to the entire world. These scientific and technological findings contribute to shaping the contents of exegetical works comprising new elements of scientific patterns of interpretation in addition to other patterns of Qur'anic interpretation (Syarifuddin \& Azizy, 2014). In addition to the introduction of scientific elements as of new patterns of interpretation to the formal works of tafsir , there 
also emerge the writing of small treatises and compendia in form of books expounding specific themes on scientific understanding of the Quran, especially concerning the cosmic verses in various disciplinary perspectives. To analyze further such interesting findings, we may relate the rise of a thematic scientific genre in the development of tafsis literature in Indonesia to what Daniel Patte (1976) called as the "structural exegesis". Borrowing the linguistic structural theories of Ferdinand de Saussure and Claude Levi-Strauss to examine the share framework in hermeneutics, Patte underlined that the present culture tends to be man-centered - not cosmos-centered anymore, meaning that one's presupposition to the interpreted text depends on his "view of man" rather than upon his "worldview". Accordingly, for him "modern conviction about a human can be characterized as dialectical. Man is considered the creator of "significations" (such as meaningful entities, cultural values, symbols and many others), and as being conditioned upon which significations are imposed." (Patte 1976: 2) Consequently, in the development of tafsir literature, an exegete chooses or even invents his own method of interpretation, even though at the same time those methods enforce him to employ them. Hence, every series of methods identify a pre-understanding upon a text. The alteration of methods follows the change in the pre-understanding possessed by an exegete. From here we can see an obvious structural interconnection between man's thought and the educational backgrounds he has encountered and experienced (Syarifuddin 2015: 8).

The early development of such works of thematic scientific interpretation in Indonesia was shaped by the publication of a book titled Al-Qur'an dan Perkembangan Alam Raya by Muhammad Munir Faurunnama (1979). He is known to be the pioneer of thematic scientific exegetical works in the field of astrophysics in Indonesia. A few years later, there appeared another scientific work in a general theme titled Islam and Modern Science by Ahmad Baiquni (1983). Besides, there are also books comprising specific themes such as Syahminan Zaini's Mengenal Manusia Lewat al-Qur'an (1984) as well as M. Ali Husain's Gizi dalam al-Qur'an (1985).

In the mid-1990s, there appeared another thematic work written by Ahmad Baiquni in his two anthologies titled Al-Qur'an, Ilmu Pengetahuan, dan Teknolologi (1994) and Al-Qur'an dan Ilmu Pengetahuan Kealaman (1996). These two books attempt to expose the close connection between the Qur'an and the scientific interpretation of its cosmic verses. In addition, the reciprocal relations also exist in between the modern scientific findings and the scientific interpretation of the Qur'an itself.

The scientific interpretation in the field of Islamic philosophy is represented by Sirajuddin Zar and Nasaruddin Umar in their shared work titled Konsep Penciptaan Alam dalam Pemikiran Islam, Sains, dan al-Qur'an (1994). Meanwhile, in the field of psychology can be seen in Dadang Hawari's Al-Qur'an, Ilmu Kedokteran Jiwa, dan Kesehatan Jiwa (1995). In form of an encyclopedic work, there appears Muchtar Naim's Kompendium Ayat-ayat yang berkaitan dengan Biologi dan Kedokteran (1996). In 1997, then appeared an anthology of writing produced in the International Seminar on the Miracles of the Qur'an titled Mukjizat al-Qur'an dan As-Sunnah tentang IPTEK. Among the authors contributed their articles to the proceeding are Abdul Majid bin 'Aziz alZindani, A. M. Saefuddin, and also Zakiah Daradjat.

After the turn to the second millennium during the early 2000s, there was a growing tendency to the thematic method of Qur'anic interpretation, especially in exploring its scientific pattern of understanding. Some works that emerged in this period are Syamsul Azhar's Sains \& Teknologi Membuka Tabir al-Qur'an (2001), Muchtar Naim's Kompendium Ayat-ayat yang berkaitan dengan Geografi dan Fisika (2001), M. Darwis Hude's Cakrawala Ilmu al-Qur'an (2002), and Ahmad Marconi's Bagaimana 
Alam Semesta Diciptakan: Pendekatan al-Qur'an dan Sains Modern (2003). There are also several scientific interpretations that relate to "mathematics of the Qur'an" as shown by works Arifin Muftie (2004), Kh. Fahmi Basya (2004, 2007), Abdussakir (2006), and Abah Salma Alif Sampayya (2007). This last perspective was introduced to enrich the discussion of the scientific miracles of the Qur'an beyond the general perspective, as reviewed in the works of Bambang Pranggono (2005), Hakim Muda Harahap (2007), and Agus Haryo Sudarmojo (2008).

Some perspectives related to the theme on nutrition reappear more than two decades after its first introduction in Tien Ch. Tirtawinata's Makanan dalam Perspektif alQur'an dan Ilmu Gizi (2006) and Emma Pandi Wirakusumah's Sehat Cara al-Qur'an dan Hadis (2010). In the field of Physics Wisnu Arya Wardhana (2004, 2006), Agus Mulyono and Ahmad Abtokhi (2006), and Agus Purwanto (2008) have contributed significant attention to the scientific study of the Qur'an in Indonesia.

The development of thematic scientific interpretation to the Qur'an in the 2010s is not only conducted by some individuals but also involving either private or governmental institutions. A collaborative scientific thematic interpretation teams of the Ministry of Religious Affairs of Indonesia and LIPI come up with their series of scientific interpretations: Penciptaan Jagat Raya dalam Perspektif al-Qur'an dan Sains (2010a), Penciptaan Bumi dalam Perspektif al-Qur'an dan Sains (2010b), Penciptaan Manusia dalam Perspektif al-Qur'an dan Sains (2010c), Air dalam Perspektif al-Qur'an dan Sains (2011a), Tumbuhan dalam Perspektif al-Qur'an dan Sains (2011b), dan Kiamat dalam Perspektif al-Qur'an dan Sains (2011c). Some new writers appear like Azhar Amsal in his Konsep Dasar Biokimia dan Nutrisi dalam al-Qur'an, which again continue the trend of thematic study of al-Qur 'an within the perspective of science of nutrition, or also Muhammad Solikhin (2012) and Ismail Idris Musthafa (2014) to revive the trend of Qur'anic mathematics.

In 2014, a scientific thematic interpretation emerges from a slightly different perspective of extant works. For example, the work of Ridwan Abdullah Sani, Sains Berbasis al-Qur'an (2014) and the Tim Tafsir Salman ITB with their Tafsir Salman: Tafsir Ilmiah Juz'Amma (2014). In his book, Sani confirms his distinctly different allegoric method of interpretations compared to some earlier works. Meanwhile, the Tafsir Salman presents a scientific commentary of the Qur'an that is different from the formal approach conducted by the Ministry of Religious Affairs of Indonesia (2010, 2011).

Some authors also come up with their new books such as Agus S. Djamil AlQur'an Menyelami Rahasia Lautan (2012), a continuation of his previous work Al-Qur'an dan Lautan (2004), Agus Purwanto also publishes his second book titled Nalar Ayat-ayat al-Qur'an (2012). Also, Agus Haryo Sudarmojo republishes his works written in between 2008 dan 2009 with new titles as well as publishers History of Earth, Menyingkap Keajaiban Bumi dalam al-Qur'an (2013) and Benarkah Adam Manusia Pertama? Interpretasi Baru Ras Adam menurut Al-Qur'an dan Sains (2013). At last, Nurul Maghfirah publishes her encyclopedic work titled 99 Fenomena Menakjubkan dalam alQur'an (2015).

\section{Conclusion}

All of the works being studied in this research show that there is a significant influence of the cultural and educational background of the exegetes, especially related to their expertise in natural sciences to the interest of interpreting the cosmic verses of the Qur'an. This is also supported by the findings of contemporary science and technology that contribute to the emergence of either element of scientific style of Qur'anic interpretation in tafsir literature in Indonesia as well as the thematic scientific works of 
Qur'anic understanding in forms of thematic treatises and compendia. For the last category, there are three character of the thematic scientific thematic works of the Qur'anic understanding in Indonesia, namely: (1) books and compendia that present the general themes of scientific interpretation, (2) books and treatises that present various themes of discussion specifically based on a certain scientific point of view, and (3) books and anthologies are in search of scientific understanding on the miracles of the Qur'an.

\section{References}

Abdussakir. (2006). Ada Matematika dalam al-Qur'an. Malang: UIN Malang Press.

Amsal, Azhar. (2012). Konsep Dasar Biokimia dan Nutrisi dalam al-Qur'an. Banda Aceh: Pena.

Azhar, Syamsul. (2001). Sains \& Teknologi Membuka Tabir al-Qur'an. Jakarta: Kalam Mulia.

Baiquni, Ahmad. (et.al) Sonhadji, M., Abdul Jabbar; Saputrasari Tri. (1996). Al-Qur'an dan Ilmu Pengetahuan Kealaman. Yogyakarta: Dana Bhakti Prima Yasa.

Baiquni, (1994). Al-Qur'an Ilmu Pengetahuan dan Teknologi. Yogyakarta: PT Dana Bhakti Wakaf.

Baiquni, (1983). Islam dan Ilmu Pengetahuan Modern. Bandung: Pustaka.

Basya, Fahmi. (2004). Matematika al-Qur'an. Jakarta: Pustaka Quantum.

Basya, (2007). Al-Qur'an 4 Dimensi: Tulisan, Bacaan, Makna, Fakta: Matematika Islam 2. Jakarta: Republika.

Basya, (2013). Bumi itu al-Qur'an: Menguak alam semesta melalui matematika alQur'an. Jakarta: Zahira.

Djamil, Agus. S. (2004). Al-Qur'an dan Lautan. Bandung: Mizan Pustaka.

Djamil, (2012). Al-Qur'an Menyelami Rahasia Lautan. Bandung: Mizan.

Dhahabī, M. Husein. (1995). Al-Tafsìr wa al-Mufassirūn. Kairo: Mustafa al-Babi alHalabì, 2 vols.

Farmawī, 'Abd al-Hayy al-. (1977). Al-Bidāyah fì Tafsìr al-Mawdī'̄̄. Fajjala: Matba'ah al-Hadarah al-'Arabiyya.

Faurunnama, M. Munir. (1979). Al-Qur'an dan Perkembangan Alam Raya. Surabaya: Bina Ilmu.

Federspiel, Howard M. (1996). Kajian al-Qur'an di Indonesia (terjemahan Tajul Arifin). Bandung: Mizan.

Gusmian, Islah (2003). Khazanah Tafsir Indonesia, Dari Hermeneutika hingga Ideologi. Jakarta: Teraju.

Harahap, Hakim Muda. (2007) Rahasia al-Qur'an Menguak Alam Semesta, Manusia, Malaikat, dan Keruntuhan Alam. Yogyakarta: Darul Hikmah.

Hawari, Dadang. H.; Sonhadji, H.M. (1995). Al-Qur'an: Ilmu Kedokteran jiwa dan Kesehatan Jiwa. Jakarta: Dana Bhakti Prima Yasa.

Hude, H.M. Darwis (2002). Cakrawala Ilmu dalam al-Qur'an. Jakarta: Pustaka Firdaus.

Husain, M. Ali. (1985). Gizi dalam al-Qur'an. Jakarta: CV Suara Baru.

Kementerian Agama RI (2010) Al-Qur'an dan Tafsirnya Edisi Yang Disempurnakan. Jakarta: Lentera Abadi, 10 volumes.

Lajnah Pentashihan Mushaf Al-Qur'an; Badan Litbang Diklat Kemenag RI; LIPI. (2010a) Penciptaan Jagat Raya dalam Perspektif Al-Qur'an dan Sains.

Lajnah, (2010b) Penciptaan Bumi dalam Perspektif Al-Qur'an dan Sains.

Lajnah, (2010c) Penciptaan Manusia dalam Perspektif Al-Qur'an dan Sains.

Lajnah, (2011a). Air dalam Perspektif Al-Qur'an dan Sains.

Lajnah, (2011b). Tumbuhan dalam Perspektif Al-Qur'an dan Sains.

Lajnah, (2011c). Kiamat dalam Perspektif Al-Qur'an dan Sains. 
Maghfirah, Nurul (2015). 99 Fenomena Menakjubkan dalam al-Qur'an. Bandung: Mizania.

Marconi, Ahmad. (2003). Bagaimana Alam Semesta Diciptakan: Pendekatan al-Qur'an dan Sains Modern. Jakarta: Pustaka Jaya.

Mulyono, Agus; Abtokhi, Ahmad. (2006). Fisika al-Qur'an. Malang: UIN Malang Press.

Muftie, Arifin. (2004). Matematika Alam Semesta: Kodetifikasi Bilangan Prima dalam al-Qur'an. Bandung: PT Kiblat Buku Utama Bandung.

Musthafa, Ismail Idris (2014). Fakta Baru Matematika al-Qur'an: Rahasia Angka dan Huruf dalam Ayat-ayat Mutasyabihat. Jakarta: Noura Books Publishing.

Naim, Muchtar. (1996). Kompendium Ayat-ayat yang berkaitan dengan Biologi dan Kedokteran. Jakarta: Gema Insani Press.

Naim, (2001). Kompendium Ayat-ayat yang berkaitan dengan Geografi dan Fisika. Padang: CV Hasanah.

Patte, Daniel. (1976). What is Structural Exegesis? Philadelphia: Fortress Press.

Pranggono, Bambang. H. (2005). Mukjizat Sains dalam al-Qur'an: Menggali Inspirasi Ilmiah. Bandung: Ide Islami.

Purwanto, Agus. (2008). Ayat-ayat Semesta: Sisi-sisi al-Qur'an yang Terlupakan. Bandung: Mizan Pustaka.

Purwanto, (2015). Nalar Ayat-ayat Semesta-New. Bandung: Khazanah.

Rohman, Izza. (2002). "Karakteristik Kajian al-Quran di Indonesia" Undergraduate Thesis, Department of Tafsir and Hadith UIN Syarif Hidayatullah Jakarta.

Sampaya, Abah Salma Alif. (2007). Keseimbangan Matematika dalam al-Qur'an. Jakarta: Penerbit Republika.

Sani, Ridwan Abdullah. (2014). Sains Berbasis al-Qur'an. Jakarta: Bumi Aksara.

Soemabrata, Iskandar AG (2006). Pesan-pesan Numerik al-Quran. Jakarta: Republika.

Solikhin, Muhammad, H. (2012) Mukjizat Matematika al-Qur'an. Jakarta: Elex Media Computindo.

Sudarmojo, Agus Haryo. (2008). Menyibak Rahasia Sains Bumi dalam al-Qur'an. Bandung: Mizania.

Sudarmojo, (2013). Benarkah Adam Manusia Pertama? Interpretatsi Baru Ras Adam menurut Al-Qur'an dan Sains. Yogyakarta: Bunyan.

Suryana (2008). Makanan yang Halal dan Haram. Jakarta: Mitra Aksara Panaitan.

Suyūțī, Jalāl al-Dīn al-. (1967). Al-Itqān fì Ulūm al-Qur'ān, Cairo: Maktaba wa mațba'a al-Masyhad al-Ḥusaynī, 4 vols.

Syarifuddin, Moh. Anwar; dan Azizy, Jauhar. (2014), "Hubungan Islam dengan Ilmu Pengetahuan dan Teknologi dalam Literatur Tafsir Indonesia", A Report of Research Results based on accredited national publications, Puslitpen UIN Syarif Hidayatullah Jakarta.

Syarifuddin, M. Anwar (2015), "Penafsiran Tematik Saintifik al-Qur'an di Indonesia: Kajian atas Karya-karya Penafsiran Bertema Penjelasan Saintifik Ayat-ayat alQur'an", A Report of Research Results based on Accredited National Publications, Puslitpen UIN Syarif Hidayatullah Jakarta.

Tim Tafsir Ilmiah Salman ITB. (2014). Tafsir Salman: Tafsir Ilmiah Juzz 'Amma. Bandung: Mizan.

Tirtawinata, Tien. (2006). Makanan dalam Perspektif al-Qur'an dan Ilmu Gizi. Jakarta: FKUI, 2006.

Wardhana, Wisnu Arya. (2004). Al-Qur'an dan Energi Nuklir. Yogyakarta: Pustaka Pelajar.

Wardhana, (2006). Melacak Teori Einstein dalam al-Qur'an. Yogyakarta: Pustaka Pelajar. 
Wirakusumah, Emma Pandi. (2010). Sehat Cara al-Qur'an dan Hadis. Jakarta: Hikmah. Zaini. Syahminan, (1984), Mengenal Manusia lewat al-Quran. Surabaya: Bina Ilmu.

Zar, Sirajuddin; Umar, Nasaruddin. (1994). Konsep Penciptaan Alam dalam Pemikiran Islam, Sains, dan al-Qur'an. Jakarta: Raja Grafindo Persada.

Zindani, Abdul Majid bin Aziz al- (et.al) (1997). Mukjizat al-Qur'an dan As-Sunnah Tentang Iptek. Jakarta: Gema Insani Press. 